\title{
Bentuk Waham Aș-Ṣahạābah Menurut Al-Idlībi Dan Relevansinya Dengan Wacana Keadilan Sahabat
}

\section{(The Forms of Waham According to Al-Idlibi and Their Relevance to the Discourse of Companions' Justice)}

\section{Nur Kholis}

Universitas Ahmad Dahlan Yogyakarta, Indonesia

nur.kholis@ilha.uad.ac.id

DOI: $10.29240 /$ alquds.v5i1.1990

Submitted: 2020-10-01 | Revised: 2021-03-09 | Accepted: 2021-03-25

\begin{abstract}
This paper explains the forms of waham aṣ-Ṣaḥābah formulated by Salāḥuddīn al-Idlībi and its relevance to the discourse of companions' justice. In a descriptiveanalytical way, this paper seeks to review al-Idlībi's opinion regarding waham that might take place at the level of companion narrators when narrating hadiths. This paper relies on a qualitative method where the data pertinent to the discussed themes of various references are collected and analyzed. The analysis is carried out by trying to position various forms of waham highlighted by al-Idlibi in the broad framework of ma'āni alhadìis and ikhtilāf al-hadīis knowledge and then also looking at the possible relationship to the pros and cons discourse on the claim of companions' justice. This study concludes that there are seven forms of waham or mistakes that were made by some companions, followed by examples of waham narrations. This paper concludes that, in an explicit way, waham occurred among the companions did not affect their justice because mistakes in this case were not related to the aspect of justice, but to dābiț. Despite being not related directly, the criteria of aș-Ṣahābah waham offer a new perspective between the pros and cons groups on the rule of aṣ-Ṣahābah kulluhum 'udūl, namely accepting and acknowledging the companions' justice but still placing the companions as the objects of hadith research, especially in the aspect of dābit
\end{abstract}

Keywords: al-Waham, al-Idlībi, Companions' Justice, The ḍābiṭ of Companions

\begin{abstract}
Abstrak. Tulisan ini menjelaskan bentuk waham aṣ-Ṣaḥābah yang dirumuskan oleh Salāḥuddīn al-Idlībi dan relevansinya dengan wacana keadilan sahabat. Secara deskriptifanalitis, tulisan ini mencoba untuk menelaah kembali pendapat al-Idlïbi mengenai waham yang dimungkinkan terjadi pada perawi tingkat sahabat ketika meriwayatkan hadis. Tulisan ini bertumpu pada metode kualitatif dimana data-data yang berkaitan dengan tema pembahasan dari berbagai referensi akan dikumpulkan dan ditelaah. Analisis dilakukan dengan mencoba menempatkan berbagai bentuk waham yang disorot oleh alIdlibi pada kerangka besar ilmu ma‘āni al-ḥadīs dan ikhtilāf al-ḥadīs kemudian melihat
\end{abstract}


juga kemungkinan hubungannya pada wacana pro kontra atas klaim keadilan sahabat. Kajian ini menyimpulkan ada tujuh bentuk ke-waham-an atau kekeliruan yang pernah dilakukan oleh beberapa sahabat disertai dengan contoh periwayatan yang waham. Tulisan ini berkesimpulan bahwa secara eksplisit dimungkinkannya sahabat mengalami waham tidaklah berpengaruh pada keadilan mereka sebab kekeliruan dalam hal ini tidak berhubungan dengan aspek keadilan, melainkan ke-ḍābiț-an. Meski tidak berhubungan langsung, kriteria waham aș-Ṣaḥābah menawarkan satu cara pandang baru di antara dua kubu pro-kontra atas kaidah aṣ-Ṣahābah kulluhum 'udūl yaitu menerima dan mengakui keadilan sahabat tetapi tetap menempatkan sahabat sebagai objek penelitian hadis yang dapat diteliti khususnya pada aspek ke-ḍābiț-an mereka

Keyword: al-Waham, al-Idlībi, Keadilan Sahabat, Ke-ḍābiț-an Sahabat

\section{Pendahuluan}

Studi spesifik atas al-Waham dalam Ilmu hadis merupakan salah satu pembahasan penting yang kurang mendapatkan perhatian. Anas al-Jā'id dalam artikelnya yang berjudul "al-Waham 'inda Ruwwāh al-Hadīis menyebutkan":

"Di antara hal yang cukup aneh adalah ketika suatu pembahasan yang penting dalam ilmu Muștalāh al-Hadïं dan merupakan soalan besar baik pada sanad maupun matan hadis tetapi belum mendapat perhatian yang cukup dari ulama untuk menuliskan pembahasan tersebut secara independent dan babkan belum menjelaskannya secara rinci, baik itu di dalam kitab-kitab 'ulüm ul-hadìis, rijäl maupun ilal al-hadis dan selainnya... Padahal kenyatannya, wabam (kekeliruan) merupakan hal yang lumrah terjadi pada semua abli hadis yang tidak terbindar dari kesalahan dan ketergelinciran dan begitu pula kekeliruan itu juga dapat terjadi pada perkataan dan ketetapan-ketetapan dari abli hadis."

Kutipan di atas setidaknya menunjukkan dua fakta penting. Pertama, belum ada satu kitab tersendiri yang membahas al-waham dalam ilmu hadis secara khusus. Dalam keterangan yang lain, Anas al-Jā'id menyatakan bahwa para imām al-ḥadīis, seperti al-Bukhāri, Ibn Hibbān, Ibn Hajar, aż-Żahab̄̄, Abū Ḥātim, dan atTirmiżi banyak memberikan predikat al-waham pada sebagian periwayat dalam kitab-kitab mereka. Meski demikian, para imam hadis tersebut belum menulis satu kitab khusus untuk mengulas persoalan ini.

Kedua, kekeliruan (al-waham) dapat terjadi pada semua ahli hadis yang tentunya tidak terbebas dari kesalahan (ghairu ma'sümin). Statement Anas al-Jāoid ini diamini pula oleh beberapa ahli hadis. Misalnya saja, aż-Żahabī yang menyatakan bahwa terhindar dari kekeliruan dan kesalahan bukan syarat dari

1 Anas al-Jā’id, "al-Waham 'inda Ruwwāh al-Ḥad̄̄̇̀", Gaziosmanpaşa Üniversitesi İlahiyat Fakültesi Dergisi, 2 no. 1 (2014) 209-234. 
predikat $\dot{s i q a h, ~ s e b a b ~ s i a p a ~ d i ~ a n t a r a ~ p e r i w a y a t ~} \dot{s} i q a h$ yang tidak pernah keliru? $?^{2}$. Tidak jauh berbeda, Ibn Hiibbān juga berpendapat, pada umumnya setiap periwayat yang hafal hadis dan menyampaikan hafalan tersebut, pernah keliru. ${ }^{3}$

Urgensi membahas al-waham dalam hadis semakin penting dan menarik apabila dikaitkan dengan Sahabat Nabi saw. Hingga kini, diskusi mengenai sahabat dalam kaca mata hadis lebih banyak pada perdebatan mengenai status keadilan semata. Didapati bahwa diskusi mengenai hal itu diframing pada kaca mata prokontra terhadap status keadilannya. ${ }^{4}$ Bagi yang pro, memandang bahwa sahabat memiliki kedudukan penting dalam Islam. Selain karena kemuliaan generasi ini didasarkan pada dalil naqli ${ }^{5}$, juga karena mereka merupakan transmitter awal yang menyampaikan hadis. ${ }^{6}$ Dengan demikian, keterjaminan pribadi mereka harus senantiasa diyakini ${ }^{7}$, sebab jika tidak maka itu berimbas pada otentisitas M) Juz. 3, 141

${ }^{2}$ Syamsuddīn aż-Żahabī, Mì̃àn al-I’tidàl fì Naqd ar-Rijäl, (Beirut: Dār al-Ma’rifah, 1963

${ }^{3}$ Muhammad bin Hibban Abu Hatim ad-Darimi, at-Tsiqat, (India: Dairah al-Ma'arif alUstmaniyyah, 1973 M) Juz.VII. 17, no. 9168

${ }^{4}$ Lailiyatun Nafisah dan Moh. Muhtadar dalam artikel yang berjudul "Wacana Keadilan Sahabat Dalam Pandangan Ulama Klasik dan Kontemporer" menyatakan bahwa keadilan kolektif semua sahabat dipegangi oleh ulama-ulama klasik berdasarkan argumentasi yang bersifat dogmatis yaitu melalui interpretasi terhadap beberapa ayat al-Qur'an dan Hadis. Sementara pihak yang menggugat prinsip keadilan sahabat itu adalah ulama kontemporer dengan memaparkan dali-dalil historis, seperti Abu Rayyah. Lailiyatun Nafisah Moh, Muhtador, "Wacana Keadilan Sahabat dalam Pandangan Ulama Klasik dan Kontemporer" Al-Quds: Jurnal Studi Alquran and Hadis 2, no.2 (2018): 153-170, doi: 10.29240/alquds.v2i2.429.153-170. Jika mengkaji lebih ke belakang lagi, maka hakikatnya ketidaksetujuan atas kaidah ini sudah ada semenjak masa klasik. Misalnya penolakan kaum khawarij dan syiah terhadap beberapa sahabat yang memang tidak sejalan dengan ideologi mereka.

${ }^{5}$ Nūruddīn 'Itr menyebutkan di antara ayat al-Qur'an yang menunjukkan kemuliaan generasi sahabat adalah Ali Imran ayat 110: "kalian adalab umat terbaik yang mengeluarkan manusia...) dan al-Baqarah ayat 143: "dan demikianlah kami jadikan kalian umat yang wasat agar kalian menjadi saksi atas manusia dan adalah Rasulullah menjadi saksi terhadap kalian" menafsirkan ayat ini, Nūruddīn 'Itr menyebutkan bahwa meskipun lafal pada ayat ini bersifat umum, tetapi menunjukkan makna yang khusus yaitu kepada para sahabat. Adapun dalil dari hadis yang menguatkan keistimewaan sahabat di antaranya adalah hadis yang menyebutkan: "sebaik-baik manusia adalah yang berada pada generasiku, kemudian selanjutnya, kemudian selanjutnya” hadis ini disebutkan oleh Nūruddīn 'Itr sebagai hadis mutawatir yang diriwayatkan oleh sebagian besar dari para sahabat. Nūruddīn 'Itr, Manähij al-Muhaddisīn al-'Ámah fì Riwāyah wa at-Taṣnîf, (Damaskus: Dār Thayyibah ad-Dimasyqiyyah, 2008 M) 55

${ }^{6}$ Miftahul Asror dan Imam Musbikin, Membedah Hadits Nabi Saw, (Yogyakarta: Jaya Star Nine, 2015) 194-195.

7 Perihal keterjaminan pribadi sahabat, Khațīb al-Baghdādī sampai mengeluarkan statement sebagai simpulan atas dalil yang mendasari keistimewaan generasi sahabat:

Segala informasi (keterangan al-Qur'an dan hadis yang berbicara mengenai keistimewaan sahabat) pada pengertian ini mengalami perluasan, setiap informasi tersebut sesuai dengan makna 
keseluruhan hadis yang tersampaikan. Oleh karenanya, mayoritas ulama sunni mengakui bahwa semua sahabat adil berdasarkan kaidah aș-șahäbah kullubum 'udūl (semua sahabat terjamin keadilannya). ${ }^{8}$

Berlainan dengan itu, ada juga pihak yang mempertanyakan ulang status keadilan kolektif tersebut. Beberapa argumen penolakannya bersifat ideologis seperti dari kalangan khawarij dan syiah. ${ }^{9}$ Sementara gugatan yang datang dari cendekia kontemporer lebih kepada fakta sejarah dan pribadi personal. Mereka menyatakan bahwa terdapat fakta-fakta historis yang menunjukkan bahwa sahabat pun melakukan kesalahan yang tidak sederhana. Seperti kelompok sahabat yang tidak ikut instruksi Nabi ketika perang di mana hal itu menyebabkan kekalahan dan polemik terjadinya pertentangan internal di antara mereka yang dipicu oleh kepentingan politik. ${ }^{10}$ Sahabat secara individu pun tidak lepas dari kritikan, seperti Abu Hurairah yang diklaim punya pandangan anti-feminis oleh Fatima Mernissi. ${ }^{11}$ bahkan beberapa gugatan tersebut didasari langsung dengan argumen naqli seperti tuduhan fasik yang dialamatkan kepada sahabat al-Walid bin 'Uqbah berdasarkan al-Hujurat ayat 6 . Melihat fakta-fakta itu, menurut mereka sulit rasanya menerima kaidah umum yang menyatakan semua sahabat adil.

Semua perdebatan tersebut mengarah kepada pro-kontra secara umum dan belum ada yang secara spesifik mengaitkannya dengan kemungkinan

yang datang dari nas al-Qur'an. Semuanya menetapkan kesucian sahabat dan kepastian dari keadilan dan kebersihan mereka (dari ketercelaan). Sehingga bersamaan dengan keterjaminan adil dari Allah, tidak satupun dari para sahabat yang butuh atas penilaian adil dari selain Allah. Sehingga para sahabat akan senantiasa berada pada sifat ini, kecuali apabila telah dipastikan bahwa salah satu di antara mereka melakukan maksiat yang mana tidak dimungkinkan hal itu terjadi kecuali memang niatnya untuk bermaksiat dan tidak dimungkinkan tindakan itu dimaknai berbeda. (jika memang itu dipastikan terjadi) maka gugur atasnya predikat adil tersebut. Namun demikian Allah telah membebaskan mereka para sahabat dari kemungkinan yang demikian itu. al-Khaṭīb al-Baghdadī, al-Kifäyah fì Tlm ar-Riwäyah, (Madinah: Maktabah al-Ilmiyyah, t.th) 48

${ }^{8}$ Nūruddīn 'Itr, Manhaj an-Naqd fì Ulüm al-Hadìs Beirut: Dār al-Fikr, 1981

${ }_{9}$ A'zami menyebutkan bahwa meskipun khawarij masih menggunakan hadis-hadis Nabi saw dan mempercayainya sebagai sumber hukum Islam, akan tetapi mereka tetap menolak hadis yang diriwayatkan oleh sahabat-sahabat yang berkaitan langsung dengan peristiwa tabkim. Mustafa A'zami, Hadis Nabi saw dan Sejarah Kodifikasinya, Terj. Ali Mustafa Ya'qub (Jakarta: Pustaka Firdaus, 1994), 42. Sementara Syiah adalah kelompok yang juga mengkafirkan sebagian sahabat. Menurut mereka, kedudukan subbah kepada Nabi yang dimiliki oleh generasi sahabat tidak bisa menjamin sifat adil. Karenanya dalam tubuh syiah mengkritik semua sahabat di luar dari ablu al-bait adalah hal yang sah untuk dilakukan. Al-Qāọi Abū Bakar Ibn al-'Arabī, al-Awāsim min al-Qawāsim fì Tah quiq Mawāqif aș-Sahăäbah ba'da Wafäh a-Nabi saw (Beirut al-Maktabah al-Ilmiyyah, 1987). 32-34

${ }^{10}$ Ahmad Amin, Fajr al-Islam, terj. Zaini Dahlan, (Jakarta: Bulan Bintang, 1986), 278

${ }^{11}$ Realitanya, kritikan terhadap Abu Hurairah tidak hanya datang dari Fatima Mernissi saja, beberapa tokoh pun memberikan kritikan seperti Abu Royyah. Kritikan-kritikan tersebut juga telah dijawab oleh beberapa ulama yang tidak meragukan pribadi Abu Hurairah sebagai sahabat yang paling banyak meriwayatkan hadis. di antara karya tersebut adalah Difä’ an Abì Hurairab karya al-Izzī. 'Abd al-Mu’in Șaliḥ al-Āli Al-'Izzī, Difā' 'an Abi Hurairah, (Beirut: Dār al-Qalam, 1981). 
kekeliruan (al-waham) yang dapat terjadi pada sahabat. Adalah al-Idlibi, seorang ahli hadis abad ke-19 membahasnya dengan menulis secara khusus tujuh bentuk ke-hawam-an yang dapat dilakukan oleh periwayat hadis, termasuk para sahabat. ${ }^{12}$ Tulisan ini mencoba mengelaborasi lebih jauh tujuh kriteria waham aș-șahăabah tersebut dalam rangka menjawab beberapa rumusan persoalan ilmiah, di antaranya (1) bagaimana bentuk-bentuk waham sahabat dalam periwayatan hadis? (2) bagaimana relevansi kewahaman sahabat terhadap wacana keadilan sahabat?

Sebagaimana yang telah dinyatakan sebelumnya bahwa wacana keadilan sahabat memang telah lama dikaji. Banyak karya telah mengulas diskursus ini dari berbagai sudut pandang. Misalnya saja dari kitab-kitab mu'tabar yang membahas hal ini dengan sangat mendalam seperti Usdu al-Ghäbah fì Tamyì aș-Șahäăah karangan 'Izzuddīn ibn al-Asīir. ${ }^{13}$ Karya yang bersifat ensiklopedis ini bisa dikatakan sebagai salah satu referensi induk dalam melacak biografi para sahabat yang disusun secara abjad. Begitu pula al-Ișäbah fi Tamyì aș-Sạabah karangan ulama hadis kenamaan Ibn Hajar al-'Asqalāni. Kitab ini juga diakui sebagai salah satu kitab yang membahas sahabat dengan sangat komperhensif, termasuk di dalamnya adalah argumentasi secara naqliyyah maupun aqliyyah yang mendasari kemuliaan sahabat yang mana argumentasi ini banyak dirujuk oleh penulis-penulis setelahnya. ${ }^{14}$

Adapun karya-karya yang ditulis dengan tujuan khusus mengkritik klaim pihak yang meragukan keadilan sahabat di antaranya adalah Difä' 'an Sunnab wa Rad Syubh al-Mustasyriqin wa al-Kitäb al-Mu'ạsirin karya Abū Syuhbah ${ }^{15}$, dan asSunnah wa Makānatuhā fì at-Tasyrì al-Islāmi karya Muștafāa as-Sibāái. ${ }^{16}$ Sementara beberapa tulisan yang mengulas kelemahan kaidah keadilan sahabat di antaranya Fajr al-Islām karya Aḥmad Amīn ${ }^{17}$ dan 'Aḍwà' 'alā as-Sunnah al-Muhammadiyah

12 Ṣalāḥuddin Aḥmad Al-idlībi, Manhaj Naqd al-Matn Inda 'Ulamä' al-Hadïs An-Nabawì Beirut: Dar al-Afaq al-Jadidah, 1983.

${ }^{13}$ Izuddīn Ibn al-As̀īin, Usdu al-Ghäbah fì Ma'rifah aṣ-Ṣahābah, (Beirut: Dār al-Kutub alIlmiyyah, 1994 M)

14 Ibn Ḥajar al-'Asqalāni, al-Ișābah fì Tamyì aș-Ṣaḥäbah, (Beirut: Dār al-Kutub alIlmiyyah, $1415 \mathrm{H}$ )

${ }^{15}$ Abu Syuhbah, Difä' 'an Sunnah wa Radd Syubh al-Mustasyriqin wa al-Kitäb al-Mu'äșirīn, (Kairo: Majma’ al-Buhūì al-Islamiyyah, $1985 \mathrm{M}$ )

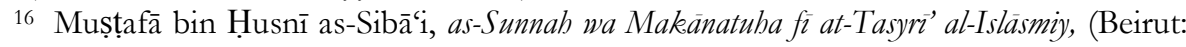
al-Maktabah al-Islāmī, $1982 \mathrm{M}$ )

${ }_{17}$ Ahmad Amin, Fajr al-Islam, terj. Zaini Dahlan, (Jakarta: Bulan Bintang, 1986) 
karya Abū Rayyah ${ }^{18}$ serta tulisan Fatima Mernissi yang khusus menyoroti Abū Hurairah yang dianggap sebagai sumber hadis-hadis misoginis. ${ }^{19}$

Sababat Nabi, Siapa, kemana dan Bagaimana merupakan salah satu buku yang juga membahas mengenai sahabat utamanya bersebaran mereka ke berbagai daerah. ${ }^{20}$ Disertasi Fuad Jabali yang kemudian dibukukan, ini secara mendalam juga membahas istilah sahabat dan secara tidak langsung memaparkan proses perkembangan definisi sahabat serta motif yang mengikutinya. Meski secara tidak langsung, Fuad Jabali dalam karya ini menempatkan dirinya pada pihak yang tidak sepakat terhadap superioritas kaidah semua sahabat itu adil. Ia lalu mengulas kembali motif dari berbagai argumentasi ulama yang mendukung kaidah ini dan tafsiran ayat yang dipergunakan oleh kalangan ahli hadis sebagai dasar atas kemuliaan sahabat yang ternyata berbeda dengan tafsiran dari beberapa kitab tafsir. $^{21}$

Adapun karya-karya mutakhir yang membahas persoalan keadilan sahabat di antaranya adalah tulisan Syuhudi Ismail mengenai keadilan sahabat dalam bukunya Kaidah Kesabiban Sanad Hadis. Pada tulisan tersebut, Syuhudi Ismail menganalisis secara kritis berbagai dalil yang dijadikan dasar argumentasi pihak yang menetapkan status keadilan sahabat secara mutlak. Dalam analisisnya, Syuhudi Ismail menyatakan bahwa beberapa ayat maupun hadis yang dijadikan sebagai dalil itu realitanya masih membuka interpretasi yang berbeda. Hal ini diperkuat dengan kenyataan bahwa tidak semua kehidupan sahabat itu sesuai dengan kaidah keadilan ini. Sebab, beberapa sahabat diketahui masih memiliki kebiasaan buruk, seperti mabuk, atau terjadinya konflik politik di internal sahabat sendiri. Oleh karena itu, Syuhudi Ismail berpendapat bahwa kaidah keadilan sahabat tidak bisa diklaim sebagai ijmak semua ulama, ia bisa saja dijadikan kaidah umum, tanpa menutup sama sekali peluang yang bertentangan dengan kaidah itu. $^{22}$

Artikel yang berjudul "Wacana Keadilan Sahabat dalam Pandangan Ulama Klasik dan Kontemporer" karya Lailatun Nafisah dan Moh. Muhtador. Karya ini mencoba meletakkan wacana keadilan sahabat pada dua kubu; ulama klasik dan

t.th)

${ }^{18}$ Mahmud Abu Rayyah, Adhwa 'ala as-Sunnah al-Muhammadiyah, (Kairo: Dar al-Ma'arif,

${ }^{19}$ Fatima Mernissi, Perempuan Dalam Islam, (Bandung: Pustaka, 1994 M) untuk ulasan mengenai klaim diskriminatif Abu Hurairah terhadap perempuan melalui periwayatan hadis dapat dilihat salah satunya pada jurnal Skeptisisme dalam hermeneutika Fatima Mernissi. Qaem Aulassyahied, "Skeptisisme dalam Hermeneutika Fatima Mernissi, Muwazah Jurnal Kajian Gender 8 no. 2 (2016) 185-200.

${ }^{20}$ Fuad Jabali, Sababat Nabi saw, Siapa, Ke Mana, dan Bagaimana?, (Jakarta: Mizan, 2010.)

${ }^{21}$ Lebih lengkapnya dapat dilihat pada Nur Fadilah, "Keadilan Sahabat Nabi dalam Perspektif Fuad Jabali, Mutawatir Jurnal Keilmuan Tafsir Hadis 2 no.1 (2012) 111-127

22 Syuhudi Ismail, Kaidah Kesabihan Sanad Hadis, (Jakarta: PT Bulan Bintang, 1998) 167174 
kontemporer. Dalam simpulannya, ulama klasik merupakan pihak yang mendukung penuh kaidah keadilan kolektif untuk seluruh sahabat, sementara kritikan atas kaidah ini datang dari ulama kontemporer. Perbedaan ini disebabkan salah satunya oleh perbedaan metodologi dalam menilai periwayat. Bagi ulama klasik, al-jarh wa at-ta'dil tidak perlu lagi dilakukan pada tabaqah generasi sahabat, sementara bagi ulama kontemporer, sahabat pun tidak keluar dari objek penelitian ketika mengkaji validitas sanad hadis. ${ }^{23}$

Kajian mutakhir lain mengenai sahabat datang dari artikel yang ditulis oleh Muhammad Anshori dengan judul "Konsep Sahabat Menurut Maḥfūẓ atTarması”. Dalam tulisan ini, dibahas salah satu karya Ulama Hadis Nusantara Manbaj Zawi al-Nażar dengan mengerucutkannya pada konsep sahabat menurut at-Tarmasī. Penelitian ini menyimpulkan bahwa at-Tarmasì merupakan salah satu ulama di bidang hadis yang diakui keulamaannya oleh dunia internasional. Namun demikian, ulasan mengenai konsep sahabat dalam kitabnya, tidak memiliki perbedaan dengan ulasan ulama sunni pada umumnya. Persamaan itu terjadi karena memang kitab ini ditulis sebagai syarh dari kitab Nazm Alfyyyah karya asSuyūti. Kalau pun ada perbedaan, hanya terletak pada bahasa yang lebih dapat dipahami. ${ }^{24}$

Karya dan penelitian yang telah dipaparkan di atas menunjukkan belum adanya penelitian yang secara spesifik membahas kriteria waham aș-șahäbah yang dirumuskan oleh al-Idlībi dan melihat relevansinya dengan wacana keadilan sahabat. Adapun mengenai pembahasan waham dalam hadis itu sendiri, sepencarian penulis ada satu karya yang membahasnya, yaitu Anas al-Jācid dengan judul al-Wabm inda Rumwäh al-Hadïs. Meski membahas secara independent konsep waham pada periwayat hadis, tapi di dalamnya belum ada pembahasan yang mendalam mengenai kekeliruan seperti apa yang dapat dilakukan sahabat dan bagaimana dampaknya pada status keadilan mereka. Di sinilah tulisan ini menemukan nilai novelty dan urgensi untuk diteliti lebih lanjut.

\section{Pengertian Waham dan kaitannya dengan ilmu 'Ilal al-Hadīis.}

Meski kata waham merupakan satu istilah yang tidak jarang diucapkan oleh para ulama ketika memberikan penilaian kepada hadis tertentu, baik itu wahm sanadnya, matannya, atau sanad dan matan sekaligus, tapi para ulama tersebut belum merasa penting untuk membahas secara independent dan komprehensif.

${ }^{23}$ Lailiyatun Nafisah, Moh. Muhtadar, "Wacana Keadilan Sahabat Dalam Pandangan Ulama Klasik dan Kontemporer" Al Quds Jurnal Studi Alquran dan Hadis 2 no. 2 (2018)

24 Muhammad Anshory, "Konsep Sahabat menurut Mahfuzh at-Tarmasi", UNIVERSUM jurnal Keislaman dan Kebudayaan 11 no. 1 (2017) 155-163 
Sehingga seperti apa pastinya maksud dari predikat waham, apa kriterianya dan bagaimana menentukan waham merupakan soalan yang perlu diteliti lebih mendalam.

Jika ditelusuri lebih jauh, ternyata konsep al-waham ini dapat ditemukan pembahasannya baik secara eksplisit maupun implisit pada konteks "illah al-hadïं, atau Muhammad 'Ajjaj al-Khatib menyebutnya Tlm Tlal al-Hadis. Salah satu buku yang membahas tentang 'illah al-hadïs secara komprehensif adalah kitab "al-'Illah wa Ajnäsuba "inda al-Muhaddis̀īn" yang dikarang oleh Abū Sufyan Muștāfa Bāhu. Dalam kitab tersebut beliau menyebutkan bahwa pembahasan dalam buku ini adalah untuk mengetahui waham para rawi dalam riwayat-riwayat mereka. ${ }^{25}$ Secara tidak langsung, Mușțāfa Bahu mengaitkan antara aś-siqät dalam hadis dengan ilmu 'Ilal al-Hadìis.

Dari segi bahasa, kata al-waham bisa dibaca al-waham (dengan men-fathahkan huruf ha) dan al-wahm (dengan men-sukun-kan huruf ha). Jika dibaca al-waham maka ia adalah bentuk mașdar dari kata kerja wahima, namun jika dibaca al-wabm, maka ia adalah bentuk mașdar dari kata kerja wahama. Ibn al-Qațtān al-Fāsyi menjelaskan bahwa jika merujuk pada pengertian keliru, atau tergelincir, maka yang benar adalah al-waham dengan fi'il wabima. Hal ini bisa ditelaah dari kitab alQämus. Di sana menyebutkan, jika dikatakan wabima fi al-hisäb artinya "keliru" (galita), namun jika wahama fí as-sya"i artinya "cenderung pada sesuatu itu" (żababa wabmubu ilaibi). ${ }^{26}$

Dalam Lisān al-'Arab juga dijelaskan demikian secara panjang lebar. Lafal wahima berarti galita (keliru). Misalnya, dalam hadis dinyatakan bahwa orang sujud sabwi itu karena waham, berarti waham di sini artinya "keliru" (annabu sajada lil wahami..: ay lilgalat). Adapun wahama seperti wahama ilaibi, mașdar-nya wahman, artinya "cenderung pada". Dalam kalimat wahamtu 'ilà as-syai'i, artinya "hati mu cenderung pada sesuatu, tetapi engkau ternyata menghendaki atau mendapat yang lain" (żababa qalbuka ilaibi, wa anta turidu gairabu). Adapun wahima berarti galita dan sabä (keliru dan lupa). Dalam kalimat wahimtu fì al-hisäb wa gairibi, artinya "keliru akannya" atau "lupa" (galita fibi wa sahawtu). ${ }^{27}$

Selaras dengan makna secara bahasa di atas, Ibnu al-Qatțān menyatakan bahwa makna yang benar dari penjelasan waham kaitannya dengan hadis ini adalah makna dari kata wahima-wahamun yaitu keliru, dan tidak sejalan dengan makna dari

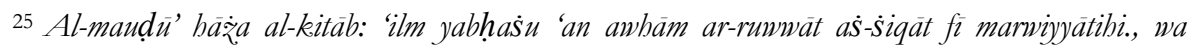

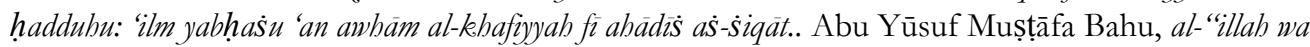
Ajnäsuba 'inda al-Muhaddisìn, (Thanta: Dār aụ-Diyā, 2005 M), 8

${ }^{26}$ Al-Ḥāfiz Ibn al-Qatțān al-Fāsyi, Bayān al-Waham wa al-Iyham al-Waqi'in fì Kitāb alAhkeàm, Jilid-1 (Riyaḍ: Dar Țībah, 1997 M), 222

${ }^{27}$ Ibnu al-Manẓūr, Lisān al-'Arab, jilid 12, (Beirut: Dār al-Fikr, 1410), 643-644 
kata wahama-wahmun yang memiliki makna asli cenderung. Bagi yang membacanya wahmun, dimungkinkan mereka menyamakan makna dari dua wazan mașdar yang berbeda, atau bisa jadi mereka belum tahu perbedaan antara makna keduanya secara bahasa. ${ }^{28}$

Pengertian waham secara bahasa ini memberi beberapa titik penekanan. Pertama, bahwa adanya waham merupakan kekeliruan yang mana hal itu mengandung arti terjadinya kesalahan tanpa disengaja. Bisa dilihat dari pengertian secara bahasa bahwa keliru tersebut disertai dengan keyakinan pelakunya bahwa yang dia lakukan adalah benar. Kedua, karena sesuatu yang tidak disengaja, dan secara zähir diyakini benar, maka waham ternyata disebabkan oleh sesuatu yang samar lagi tidak jelas. Hal itulah yang menyebabkan pelakunya meyakini perbuatannya benar.

Dua penekanan ini, jika dikaitkan pada kajian hadis maka akan mengantarkan pada pengertian istilah bahwa yang dimaksud hadis wabam atau waham al-hadis adalah hadis yang di dalamnya terdapat kekeliruan yang disebabkan oleh periwayatnya secara tidak disengaja. Sifat kekeliruan yang tanpa sengaja dan samar ini, oleh para ahli hadis tercakup dalam pengertian 'illah dalam ilmu hadis, dan dibahas dalam tema 'ilal al-hadïs.

Sebagaimana yang diketahui bahwa illah menurut jumbür al-muhaddisin adalah ungkapan atas sesuatu yang samar yang menjadi sebab cacatnya sebuah hadis, sementara secara $z a ̈ h i r$ hadis tersebut selamat dari sebab itu. ${ }^{29}$ Pengertian ini juga diikuti oleh Ibnu Șalāh, an-Nawawī, dan al-'Irāqii. ${ }^{30}$

Pengertian 'illah ini menetapkan sejumlah karakter: Pertama, 'illah bisa masuk di sanad, matan atau sanad dan matan sekaligus, karena pada pengertiannya tidak ada batasan. Kedua, 'illah masuk pada hadis-hadis yang pada umumnya sudah dianggap sahih , sebelum adanya penelitian secara mendalam dari hadis tersebut. Ketiga, 'illah itu bersifat tersembunyi dan mendalam. Keempat, 'illah

${ }^{28}$ Al-Ḥāfiz Ibn al-Qaț̣ān al-Fāsyi, Bayān al-Waham... 223

${ }^{29}$ Tbärah 'an sabäb gämị̆ kbafiy yaqdahu fi sihḥah al-ḥadìs ma'a anna az-zähira as-salämah minhu. Abu Yūsuf Muștāfa Bahu, al-"illah wa Ajnäsuba inda al-Muhaddis̄in, (Thanta: Dār aḍ-Dịā, $2005 \mathrm{M}), 19$

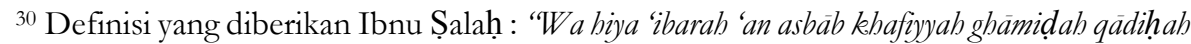
fỉhı”. Ibnu Șalah, Muqaddimah Ibnu Șalah, (Kairo: Dār al-Ma’ārif, t.t), 114. Adapun dari an-Nawāwi "wa al- "illab: 'Tbrah 'an sabab gämid khafiy qädih ma'a anna az-zähir as-Salämah minhu”. An-Nawawi, at-Taqrīb wa at-Taysìr li Ma'rifah Sunan al-Basyir an-Nà̃̀ì, (Beirut: Dār al-Kitāb al-'Araby, 1985 M), 252. Begitu juga dengan al-'Iraqi : "Wa al- "illah 'Tbārah 'an asbāb khafíyyah gämidah țara'at 'alā alhadìis, fa as arat fibi, ay qadihat fi șihh hatib". Zakaria al-Anșāry, Syarh al-Fiyah al-Irāqy: Fath al-Bäqi, jilid 1, (Beirut: Dār Kutub al-'Ilmiyyah, t.t), 226 
mencacatkan pada șahih -nya sebuah hadis, namun yang harus diperhatikan di sini bahwa lafal qadihab tidak termasuk cacat yang berat, sehingga kedustaan periwayat, atau kefasikannya atau buruknya hafalan yang itu semua adalah cacat berat lagi jelas tidak termasuk 'illah dalam hal ini. ${ }^{31}$

Berdasarkan pengistilahan waham dan illah, maka dengan jelas terlihat kaitan keduanya, di mana waham adalah adanya kekeliruan yang tidak disengaja sehingga menjadi samar, sementara "illah itu sendiri adalah cacat yang terdapat dalam sebuah hadis yang mana hadis tersebut bisa saja dianggap selamat dan diterima. Selain itu, juga menunjukkan bahwa 'illah adalah sebab adanya hadis wabam, namun tidak semua illah menyebabkan hadis itu disebut hadis yang waham, karena 'illah tidak hanya menjadikan waham, tetapi juga berada pada hadis yang dianggap marfu' ternyata mursäl, manqüf atau munqati. ${ }^{32}$

\section{Bentuk Waham aṣ-Ṣaḥābah menurut al-Idlībi}

Adanya perhatian terhadap riwayat-riwayat yang waham pada masa sahabat sebenarnya telah dilakukan oleh sahabat sendiri, misalnya saja sikap kritis 'Aisyah terhadap beberapa riwayat dari sahabat lain. Dalam kitab "al-Ijäbah li İrādi Mä Istadrakathu 'Āisyah 'alā aș-Ṣahäbah" karangan Badruddīn az-Zarkasyī, diterangkan beberapa kritik 'Aisyah terhadap riwayat yang ia yakini keliru oleh sahabat lain seperti Umar bin Khattab, Abdullah bin Umar, Ibnu Abbas, Abi Said al-Khudri, Ibnu Mas'ud, Abdullah bin 'Amr, Abu Hurairah dan lain-lain. Mereka semua tidak perlu diragukan lagi- dalam derajat periwayat yang siqab; adil dan d̦äbit, sehingga dalam hal ini, kritikan yang diberikan didasari atas ke-wabaman atau kekeliruan mereka yang bisa jadi disebabkan: (1) salah saat mendengar riwayat, (2) lupa, (3) meriwayatkan hadis yang mereka sendiri kurang jelas mengenainya, (4) mendengar akhir hadis dan luput awal hadis saat disampaikan dalam sebuah majelis karena keterlambatan mereka mengikuti majelis tersebut, (5) karena meringkas sebuah hadis, sementara terjadi kekeliruan pada ringkasan tersebut, atau (6) hadis yang harusnya dipahami khusus, diriwayatkan secara umum. ${ }^{33}$

${ }^{31}$ Abu Yūsuf Muṣțafa Bahu, al-"Illah wa Ajnāsuha inda al-Muhaddisìnn, (Thanta: Dār aḍDịā, 2005 M), 20

32 Syuhudi Ismail, Kaedah Kesabihan Sanad Hadis, (Jakarta: Bulan Bintang, 1995), 149

${ }^{3}$ Badaruddin az-Zarkasyi, al-Ijäbah li İradi Mā Istadrakathu 'Āisyah 'ala aș-Sahäbah, (Beirut: al-Maktab al-Islamy, 1970), 124-145 
Al-Idlībi ${ }^{34}$ dalam karyanya Manhaj an-Naqd al-Matn Inda Ulamä al-Hadïs an-Nabaw $n^{35}$ juga menaruh perhatian pada aspek waham dalam hadis utamanya pada pembahasan kritik matan atau yang ia istilahkan sebagai an-naqd ad-däkbilì. Menurutnya, kekeliruan dalam periwayatan hakikatnya telah terjadi sejak masa sahabat yang mana pada masa itu otentisitas hadis masih sangat terjamin, sehingga belum banyak kegiatan penelitian hadis secara terstruktur dan sistematis yang dilakukan oleh para sahabat. ${ }^{36}$ Masih menurut al-Idlībi, faktor kekeliruan yang terjadi di kalangan para sahabat juga dipicu oleh banyaknya matan hadis yang diriwayatkan secara makna yang kemudian membuka peluang terjadinya kekeliruan disebabkan adanya potensi kesalahpahaman akibat dari redaksi bi almakna tersebut. ${ }^{37}$ Selain dari itu, Faktor kekeliruan itu juga dipicu oleh adanya sahabat yang meriwayatkan sesuatu tetapi tidak bersumber dari Rasulullah, melainkan dari sahabat sendiri, ataupun dari cerita atau pernyatan ahli kitab sebagai bahan perbandingan setelah masuk Islam. Bagi al-Idlïbi, fakta ini juga bisa menjadi sebab tidak mustahilnya kekeliruan dalam menisbatkan informasi kepada Nabi saw. ${ }^{38}$

Terhadap kemungkinan kekeliruan itu, al-Idlibi membagi dua sikap yang muncul di internal sahabat sendiri. Pertama, sikap diam tanpa komentar namun juga tidak menerimanya (an yatawaqqafa aṣ-ṣahāāi mujarrad at-tawaqquf). Kedua, mengingkari dan mengkritiknya karena dinilai sebagai kesalahan dan kekeliruan dari sahabat yang bersangkutan (an yunkiraha iṭlāqan ḥamlan lahā 'alā sahw annāqil wa khațihi wa wahamihi. ${ }^{39}$

${ }^{34}$ Nama lengkapnya adalah Shalahuddin bin Ahmad bin Muhamad Said al-Idlibi. Lahir pada tahun $1367 \mathrm{H}$ bertepatan dengan $1948 \mathrm{M}$ di kota Halb atau dikenal juga dengan Aleppo Suriah. Sejak kecil al-Idlibi telah menempuh ilmu-ilmu syariah di Madrasah as-Sanawiyah asSyariah di Halb. Ia lalu melanjutkan jenjang pendidikan lebih tinggi di Fakultas Syariah, Univesitas Damaskus. Al-Idlibi melanjutkan jenjang Magister di Universias Dar al-Hadis al-Husniah di Rabat pada jurusan Ulum al-Islamiyyah wa al-Hadis. Tahun 1980 M, Ia menyelesaikan doktoral di Universitas yang sama. Aktivitas intelektualnya ditempuh pada beberapa universitas. Selain mengajar dan menjadi supervisor di Universitas Muhammad bin Suud Riyad, ia juga mengajar di Open University Makkah. Selain itu pula al-Idlibi menjadi dosen di Fakultas Dirasah al-Islamiyyah wa al-Arabiyyah Dubai dan Fakultas al-Lugah al-Arabiyyah Marakisi. Berbagai karya dan tulisan beliau dapat diakses di websiter pribadi idlbi.net.

${ }^{35}$ Șalāḥuddin bin Aḥmad al-Adlābī, Manhaj an-Naqd al-Matn Inda 'Ulamā al-Hadìis anNabawī, (Beirut: Dar al-Afāq al-Jadīdah, 1983 M)

${ }^{36} \mathrm{Di}$ antara penelitian hadis yang masyhur pada masa sahabat adalah șuhüf milik 'Amr bin al-'Ashi yang dinamakan șuhüf aṣ-șadiqqah, juga șuhüf milik Ali bin Abi Thalib dan Sa'ad bin 'Ubadah. Șalāḥuddin bin Aḥmad al-Adlābī, Manhaj an-Naqd al-Matn Inda Ulamā al-Hadīs..., 77

${ }^{37}$ Ṣalāḥuddin bin Aḥmad al-Adlābī, Manhaj an-Naqd al-Matn Inda 'Ulamā al-Hadïs..., 78

${ }^{38}$ Ibid.

${ }^{39}$ Ṣalāḥuddin bin Aḥmad al-Adlābī, Manhaj an-Naqd al-Matn 'Inda 'Ulamā al-Hadïs..., 107 
Al-Idlïbi kemudian mengumpulkan tujuh faktor yang menjadi penyebab bisa terjadinya kesalahan dan kekeliruan pada hadis yang diriwayatkan sahabat. Ia berkata $^{40}$ :

$$
\begin{aligned}
& \text { وحيث لا يوجد بين الصحابي و بين الرسول الأكرم عليه الصلاة و السلام سلسلة إسناد، بل } \\
& \text { الوسطة هي واحد من الصحابة غالبا فقط، فإن الوهم إن كان، فإنما هو من هذا الراوي } \\
& \text { الصحابي، و انما يقع له الوهم غالبا لأحد الأسباب التالية: }
\end{aligned}
$$

"Ketika di antara Nabi saw dan seorang Sababat tidak terdapat rangkaian periwayat lain, babkan hanya sababat itu sendiri dan ini yang umumnya dijumpai, maka andaikata terjadi kesalahan, kesalahan itu tidak lain berasal dari sahabat tersebut, kesalahan itu bisa disebabkan oleh salah satu faktor berikut" ${ }^{\text {*1 }}$ :

Pertama, sahabat meriwayatkan hadis yang didengarnya langsung dari Nabi saw, tetapi ia tidak tahu kalau hadis itu telah dinasakh (an yahduisa bima sami'ahu min an-Nabi wa lā yadri annahu mansükhun). Al-Idlībi memberikan contoh pada poin ini dengan riwayat mengenai kewajiban mandi junub karena keluarnya mani:

$$
\begin{aligned}
& \text { روى يعقوب بن سفيان الفسوي، عن أبي سلمة بن عبد الرحمن، قال: د خلت على عائشة } \\
& \text { فقلت: "يا أماه، ان جابر بن عبد الله يقول: "الماء من الماء". فقالت : "أخطأ، أجابر أعلم مني } \\
& \text { برسول الله ص.م. ؟ يقول: "إذا جاوز الختان الختان فقد وجب الغسل", "اوجب الرجم ولا }
\end{aligned}
$$

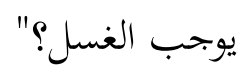

Diriwayatkan dari Ya'qūb bin Sufyān, al-Fasawi, dari Abù Salàmah bin 'Abdurrahmān, ia berkata: Aku mendatangi 'Aisyah, "Wahai ibu (umm al-Mu'minin), Jabirpernab berkata bahwa wajibnya mandi junub dikearenakan keluarnya air mani (al-Mä' min al-Mä)?." Mendengar itu, Aisyah berkomentar: "yang demikian keliru, apakah Jabir lebih mengetabui dari pada aku peribal Rasulullah saw? sementara Beliau bersabda "Jika telah masuk satu kemaluan ke kemaluan lainnya maka telab wajib mandi”. Apakah rajam wajib (karena adanya qina yaitu masuknya kemaluan pada kemaluan lainnya tanpa ada akad sebelumnya) sementara mandi tidak wajib?."

Al-Idlībi, setelah mengungkapkan keterangan ini memberikan penjelasan bahwa riwayat Jabir al-mä' min al-mà' 'itu menunjukkan wajib mandi junub apabila mani keluar, baik itu ketika bersetubuh atau lainnya. Redaksi hadis ini

40 Șalāḥuddin bin Aḥmad al-Adlābī, Manbaj an-Naqd al-Matn Inda Ulamā al-Hadïs..., 108

${ }^{41}$ Ṣalāḥuddin bin Aḥmad al-Adlābī, Manbaj an-Naqd al-Matn Inda 'Ulamā al-Hadìs..., 
menunjukkan betapa Nabi saw sangat memperhatikan diksi dan menerangkannya dengan ungkapan yang begitu halus. Akan tetapi, ketika Jabir meriwayatkan hadis ini dengan pemahaman tidak wajibnya mandi junub apabila ber-jima' tidak mengeluarkan mani, maka 'Aisyah mengkritik pemahaman itu dengan mengatakan bahwa Jabir telah keliru. 'Aisyah lalu menyebutkan hadis lain "Jika satu kemaluan telah masuk pada kemaluan lainnya (jima') maka wajib mani”.

Berdasarkan ini, al-Idlïbi menarik kesimpulan, hadis pertama yang diriwayatkan oleh Jabir itu adalah bentuk rukhṣah yang diberikan pada masa awal Islam, setelah itu hadis tersebut di-mansükh. Pada kenyataannya, terdapat beberapa sahabat yang masih meyakini riwayat tersebut karena ketidaktahuan mereka bahwa hadis itu telah dihapus oleh riwayat belakangan yang diungkapkan oleh 'Aisyah tadi. Tidak hanya menyebutkan riwayat yang menjadi näsikh atas riwayat Jabir, Aisyah juga berargumen menggunakan logika dengan menyatakan bahwa, jika terjadi jima' (zina) maka akan dihukum rajam meski tidak mengeluarkan mani, lalu bagaimana bisa mandi tidak diwajibkan jika mani tidak keluar, padahal kewajiban mandi itu lebih rendah dari kewajiban hukum had. ${ }^{42}$

Kedua, Sahabat mengalami kekeliruan dalam meletakkan dua hadis atau dua kata, sehingga meletakkan yang satu ke tempat yang satunya lagi. Ini yang disebut al-maqlüb (an yaqa'a labu inqiläban baina syai'aini aw lafżaini, fa yaj'alu kulla wähidin minbuma makān al-äkhar, wa häża huwa al-maqlüb). Sepenelusuran penulis terhadap hadis-hadis dalam kitabnya, tidak didapati satu hadis pun yang bisa menjadi contoh untuk poin kedua ini, dan barangkali inilah yang menjadi salah satu masukan terhadap karya tersebut.

Jika hendak dicari, maka didapati salah satu polemik mengenai tata cara sujud Rasulullah dapat dijadikan contoh pada poin kedua ini. Abū Hurairah meriwayatkan bahwa Nabi saw bersabda, "Apabila seseorang kamu sujud, hendaklah ia meletakkan kedua tangannya terlebih dahulu sebelum meletakkan kedua lututnya, dan janganlah ia menderum ${ }^{43}$ seperti menderumnya unta." ${ }^{\prime 4}$

Hadis ini maqlüb (terbalik) bila dibandingkan dengan hadis Abū Hurairah juga yang diriwayatkan oleh Ibn Abi Syaibah dan Wā’il Ibn Hijir yang diriwayatkan

${ }^{42}$ Șalāḥuddin bin Aḥmad al-Adlābī, Manhaj an-Naqd al-Matn Inda 'Ulamā al-Hadìs..., 129

${ }^{43}$ Menderum artinya berlutut dengan kedua kaki depan atau keempat kakinya (tentang binatang besar seperti lembu, kerbau). Kamus Besar Bahasa Indonesia, (Jakarta: Balai Pustaka, 2005), 256, kolom 1-2.

${ }^{44}$ Abū Dāwūd, Sunan Abì Dāwñu,, (Beirut: Dār al-Kutub al-'Ilmiyyah, 2007), 143, hadis no. 840, "Kitab aș-Ṣalāh, Bāb Kaifa Yaḍa’u Rukbataihi qabla Yadaih," an-Nasā’i, Sunan an-Nasā’’, (Beirut: Dār al-Kutub al-'Ilmiyyah, 2005), 187, hadis no. 1088, "Bāb Mā Yașilu ilā al-Arḍ min alInsān fi Sujūdih." 
oleh para penyusun Sunan empat yang menerangkan bahwa Nabi saw ketika hendak sujud meletakkan lututnya terlebih dahulu kemudian baru kedua tangannya. ${ }^{45}$

Ibn Qayyim berpendapat bahwa hadis Abu Hurairah yang pertama termasuk hadis terbalik (maqlüb) matannya di kalangan beberapa rāwi. Aslinya adalah "... dan hendaklah ia meletakkan kedua tangannya". ${ }^{46}$ Lebih dari itu Ibn Qayyim menjelaskan bahwa hadis ini mengandung kontradiksi internal dalam matannya karena dalam hadis ini Nabi saw melarang sujud dengan cara menderum seperti unta, namun memerintahkan meletakkan kedua tangan terlebih dahulu baru kemudian lutut. Unta ketika menderum pertama-tama merebahkan tangannya (kaki depan) sehingga tampak posisi unta itu menungging, kemudian baru merebahkan lututnya, itu sama persis seperti menderum yang dilarang dalam hadis itu sendiri. ${ }^{47}$ Atas dasar keterangan di atas, jelas bahwa Abū Hurairah dalam satu riwayatnya salah meletakkan suatu lafal yang menyebabkan hadis tersebut menjadi maqlüb.

Ketiga, dalam meriwayatkan hadis, sahabat menyertakan komentarnya bersama dengan redaksi hadis itu, sehingga diduga oleh para pendengarnya bahwa itu bagian dari hadis. Inilah yang disebut hadis mudraj (an yaqüla ma'a riwajyah alhadìs qaulan min 'indi nafsibi, muttașilan bi naș al-ḥadïs, fa yaẓunnubu as-sāmi' ùna annahu marfü'un, wa hā̇a huwa al-mudraj). Pada poin ini, al-Idlībi mencontohkannya dengan riwayat perintah berwudu' setelah memikul mayat.

Sejumlah Sahabat meriwayatkan hadis dari Nabi saw, bahwa orang yang memandikan mayat, dianjurkan mandi. Di antara Sahabat itu adalah 'Āisyah, Hużaifah dan Abū Hurairah. Adapun Abū Hurairah, dari Abī Manșūr al-Baghdādi meriwayatkan:

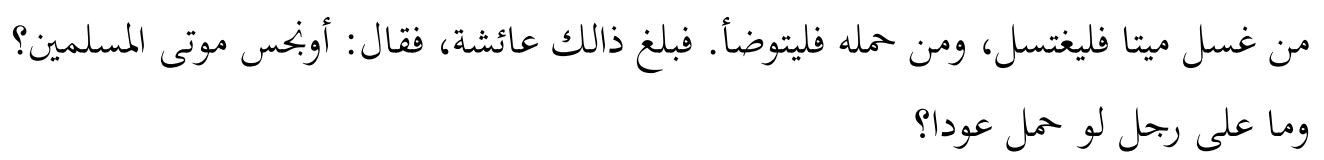

"Barang siapa memandikan mayat, maka hendaklah ia mandi, dan barang siapa yang memikulnya hendaklah ia berwudu". Riwayat ini didengar 'Äisyah, spontan beliau protes:

${ }^{45}$ Ibn Abī Syaibah, al-Mușannaf, (al-Maktabah Asy-Syāmilah, edisi II), I:294; Abū Dāwūd, Sunan Abì..., 142, hadis no. 838; an-Nasā’i, Sunan an-Nasä’’ 187, hadis no. 1086; at-Tirmiżì , Sunan at-Tirmiž̀i, (Beirut: Dār Kutub al-'Ilmiyyah, 2003), 86, hadis no. 268; Ibn Mājah, Sunan Ibn Mājah, (Indonesia, Maktabah Dahlan, t.t.), I: 286, hadis no. 886, "Bāb as-Sujūd."

${ }^{46} \mathrm{Ibn}$ al-Qayyim, Zād al-Mà'àd fì Hady Khair al-Thäd, jilid ke-1, (Beirut: Dār al-Fikr li atTibā'ah wa an-Nasyr wa at-Tauz $\overrightarrow{1}$, t.t.), 57

${ }^{47}$ Ibn al-Qayyim, Zād al-Ma'ād fì Hady Khair al-'Tbād, jilid ke-1, (Beirut: Dār al-Fikr li atTibā'ah wa an-Nasyr wa at-Tauz $\overrightarrow{1}$, t.t.), 58 
"Najiskah mayat-mayat muslim?, kalau begitu, apa yang harus dilakukan oleh orang yang memikul kayu bakar? (apakah ia wajib wudu atan tidak?)"

'Āisyah dalam keterangan ini menolak riwayat tersebut dengan alasan dia dan sahabat lainnya meriwayatkan hadis tanpa adanya lafal tambahan yang menyuruh berwudu' ketika memikul mayat. Dengan demikian, lafal perintah wudu' dalam hadis tersebut sejatinya merupakan tambahan Abū Hurairah dari pemahamanya sendiri atas hadis ini. Adapun yang mendapati setelahnya mengira tambahan itu juga marfu' sampai kepada Nabi saw. Jadilah tambahan tersebut dianggap satu kesatuan dengan hadisnya.

Dalam kritikan Aisyah juga terlihat bagaimana ia dapat memahami perintah mandi bagi si pemandi mayat, karena terkena najis dari mayat. Adapun mengenai perintah wudu' bagi si pemikul mayat, baginya suatu keganjilan sebab diketahui bersama, bahwa seorang muslim tidaklah najis. Oleh karenanya 'Āisyah bertanya dengan nada protes: "Najiskah mayat-mayat mukmin? adakah yang diwajibkan bagi orang yang memikul kayu bakar berwudu'?, kalau tidak, maka begitu juga dengan memikul mayat, karena sama-sama bukan najis". ${ }^{48}$

Keempat, sahabat meriwayatkan hadis dengan redaksinya sendiri yang memiliki cakupan lebih luas dari makna sebenarnya (an yarwiya al-hadìs fi mauridin yaj'alubu yahtamila min al-ma'na aksiar mimma yahtamil). Riwayat mengenai salat witir yang disebutkan oleh al-Idlībi menurut penulis dapat menjadi contoh poin ini.

Diriwayatkan dari Ali bin Abi Thalib, bahwa Nabi saw besabda setelah melakukan witir:

$$
\text { ياأهل القرأن، أوتروا، فإن الله وتر يحب الوتر }
$$

"Wahai pecinta al-Qur'an, berwitirlah kalian, sebab Allab itu ganjil (satu), dan menyukai yang ganjil."

Al-Idlībi menjelaskan bahwa kemungkinan besar Ali bin Abi Thalib mendengar hadis itu dari Nabi saw, kemudian meriwayatkannya secara makna dengan redaksinya sendiri. Hal itu mengakibatkan ia keliru. Imam Ahmad meriwayatkan hadis ini dengan redaksi: "siapa yang tidak melakukan witir, maka tidak termasuk golongan kami (muslimin)." Adapun aț-Ṭabarī di dalam al-Mu'jam al-Awsat meriwayatkannya dengan redaksi: "Siapa yang tidak melakukan witir, maka tiada salat baginya". 
Mendengar riwayat seperti itu, lalu Aisyah berkata:

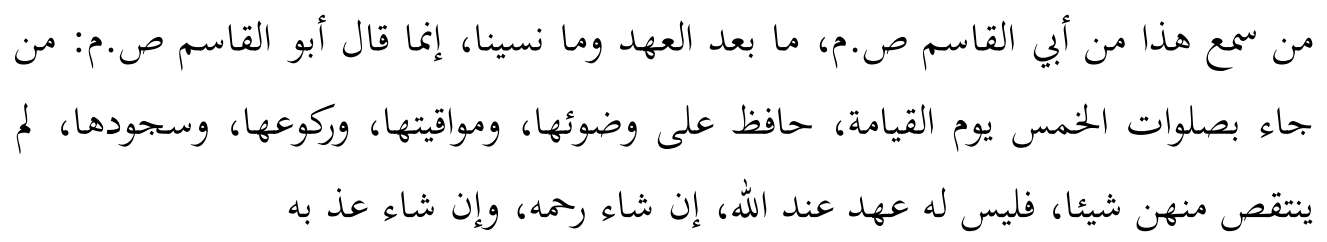

"Siapa yang mendengar riwayat ini dari Abu Qasim (Nabi saw)? Apa yang telah dijanjikan oleh Allah, kami tidak lupa itu! yang benar beliau bersabda: "barang siapa yang datang membawa catatan salat lima waktu, pada hari kiamat nanti dengan memperbatikan wudu'nya, waktunya, rukuknya, sujudnya, tanpa kekurangan sedikit pun maka Allah disebabkan karena itu berjanji kepadanya untuk tidak menyiksanya, tapi orang lain datang dengan membawa kekurangan pada salatnya, maka tidak akan memberikan janji berupa jaminan untuknya bisa menyayanginya dan bisa pula menyiksanya."

Al-Idlïbi mengambil kesimpulan bahwa 'Āisyah dalam mengkritik riwayat ini tidak membandingkannya dengan ayat al-Quran, tetapi dengan hadis Nabi saw yang telah disepakati kesahihaannya, yaitu hadis yang menyatakan salat yang wajib, lima kali sehari. Seandainya benar riwayat tentang kewajiban witir itu, maka salat yang diwajibkan enam kali. Hal ini jelas bertentangan dengan yang telah disepakati bersama melalui hadis-hadis Nabi saw yang șahih. ${ }^{49}$

Kelima, Keliru dalam menguasai dan memahami redaksi hadis sehingga menyelisihi makna sebenarnya (an laa yadbița lafz al-hadïs bibaisu yakbtalifu alma'na). Di antara hadis-hadis yang disebutkan yaitu riwayat mengenai wanita, himar dan anjing dapat membatalkan salat adalah hadis yang sesuai dengan point ini.

Muslim, Abū Dāwud, at-Tirmiżī dan an-Nasā’i meriwayatkan sebuah hadis dari Abū Żar, ia berkata, Nabi saw bersabda:

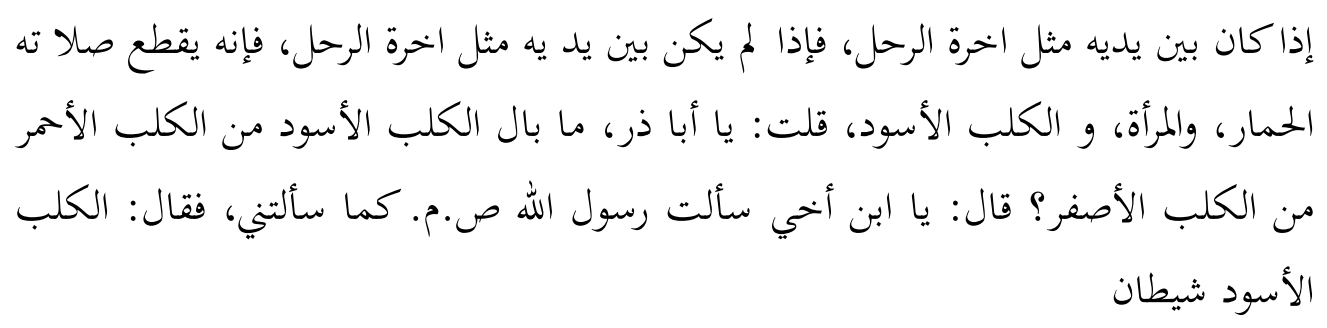

"Iika salah seorang di antara kamu bendak melakukan salat, maka cukuplah menjadi penghalang (sutrab) terdapat semisal pelana onta (atau barang bawaan). (karena) Bila dibadapanny a tidak terdapat sejenis pelana onta, maka wanita, himar dan anjing hitam dapat 
memutuskan salatnya". Aku bertanya: "Wabai Abu Żar, apa beda anjing hitam dengan anjing merah dan anjing kuning?". I menjawab: "Saudaraku, saya juga pernah menanyakan hal yang sama kepada Nabi saw, lalu ia menjawab: "Anjing hitam adalah setan".

Muslim juga meriwayatkan hadis senada, dari Abū Hurairah, ia berkata Nabi saw bersada: "wanita, himar dan anjing hitam (dapat) memutuskan salat." Hal itu bisa dilindungi dengan semisal ujung pelana onta (atau barang bawaan)."

'Āisyah sangat mengingkari riwayat-riwayat ini. Imam muslim meriwayatkan:

$$
\begin{aligned}
& \text { عن عروة بن الزبير قال: قالت عائشة: "ما يقطع الصلاة ؟" قال: فقلنا: " المرأة و الحمار، } \\
& \text { فقالت: " ان المرأة لدابة سواء؟ لقد رأيتني بين يدي رسول الله معترضة كاعتراض الجنازة، وهو } \\
& \text { يصلي" }
\end{aligned}
$$

Dari 'Unwah ibn Zubair, ia berkata, bahwa 'Āisyah bertanya: "apa yang dapat memutuskan salat?", 'Unwah berkata, kami menjawab: "wanita, himār dan anjing hitam". Beliau berkata: "kalau begitu, wanita sama dengan binatang buruk itu? Padahal aku pernah tiduran di depan Rasulullah saw, membujur seperti mayat saat beliau sedang salat".

Abū Dāwud juga meriwayatkan hadis senada dari 'Urwah dari ‘Āisyah dan melalui Abū Salām ibn 'Abdurraḥmān serta melalui al-Qāsim. Di dalam riwayat ini 'Āisyah berkata: "buruk sekali kalian membandingkan kami dengan himär dan anjing hitam".

Muslim juga meriwayatkan dari al-Aswad dan dari Masrūq, dari 'Āisyah setelah beliau diberitahu bahwa anjing, himär dan wanita dapat memutuskan salatia berkata: "kalian benar-benar telah menyamakan kami dengan himär dan anjing? Demi Allah, saya pernah melihat Rasulullah saw salat sedangkan saya sendiri berbaring di ranjang di tempat antara beliau dan kiblat. Dalam hatiku, sebenarnya terbetik "keinginan" tetapi aku enggan mengganggu beliau, karena itu aku lalu beralih berbaring di samping kedua kaki beliau".

Al-Idlïbi menjelaskan bahwa 'Āisyah mengkritik hadis itu karena ia melihat di dalamnya ada dua hal, yaitu penyebutan wanita bersama keledai dan anjing hitam serta kenyataan bahwa Rasulullah saw pernah melakukan salat, padahal dirinya ada di hadapan beliau dalam keadaan berbaring seperti mayat. Inilah yang membuatnya menolak keras hadis tersebut.

Banyak pula riwayat yang membela riwayat 'Āisyah, sebagaimana yang dipaparkan oleh Al-Idlībi. Di antaranya hadis dari at-Tirmiżì, Abū Dāwud dan anNasā’i, dari Ibn Abbas ia berkata: "saya membonceng al-Fāḍil, lalu kami datang pada saat Nabi saw salat bersama para Sahabat di Mina. Kami beristirahat di 
tempat itu. Sesampainya di barisan salat, aku lewat dihadapan mereka tetapi mereka tidak membatalkan salat.

An-Nawawi mengatakan bahwa para ulama memang berbeda pendapat mengenai hadis yang diriwayatkan tadi. Ada yang mengatakan bahwa semua itu bisa memutuskan salat. Ahmad berkata, anjing hitam memang bisa dipahami dapat memutuskan salat, tetapi mengenai himär dan wanita masih diragukan. Mālik, Abū Ḥanīfah dan as-Syāfí̄i serta jumhūr ulama salaf maupun khalaf berkata, salat seorang tidak batal karena adanya sesuatu yang lewat di hadapannya. Mereka kemudian men-ta'wil-kan hadis itu bahwa yang dimaksud 'memutuskan' salat adalah berkurangnya pahala salat karena perhatian hati dapat buyar disebabkan lewatnya semua itu.

Al-Idlībi juga mengutarakan pendapat Abu Bakar ibn al-'Araby yang menurutnya memiliki pemahaman yang baik atas pemahaman jumhūr. Ia mengatakan bahwa yang dimaksudkan "memutuskan salat" adalah mengurangi kekhusyu'an seorang atau memalingkan perhatiannya dari salat. Seandainya mengandung pengertian lain, tentu akan digunakan redaksi "membatalkan salat". Wanita memang bisa memutuskan salat karena fitnahnya, keledai juga bisa memutuskan salat karena kebebalan dan kekolotannya, ini terbukti ketika dihalau, ia tidak mau pergi. Adapun anjing hitam, umumya hati kita merasa jiik, sehingga akan membuat perhatian buyar. Warna hitam umumnya sangat kita benci, berbeda dengan warna putih, karena putih terbuat dari 'cahaya'. Karenanya, kita sering galau bila berada di tempat yang gelap. Jahannam pun, konon berwarna hitam pekat. ${ }^{50}$

Keenam, sahabat meriwayatkan hadis dengan makna yang tidak benar karena lupa atau tidak tahu latar belakang penuturan hadis tersebut (an yarwiya alhadüs 'alä gairi wajhibi ligaflatihi 'an sabäb al-wurüd). Contoh riwayat pada poin ini adalah hadis yang dikutip Al-Idlībi mengenai siksa kubur disebabkan tangisan keluarga.

Diriwayatkan dari al-Ḥākim juga, dari Abū Hurairah secara marfü:

$$
\text { إن الميت يعذ ب ببكاء الحي }
$$

"Sesunggubnya mayat akan disiksa karena tangisan orang yang mati."

Hadis ini juga diriwayatkan oleh Umar bin Khattab, 'Abdullah ibn Umar dan al-Mughīrah ibn Syu'bah juga meriwayatkan dengan redaksi yang sama, Hadīis..., 119 
seperti yang disebutkan dalam Șahịh al-Bubkari, Șahihh Muslim dan yang lain. Ibn Mājah juga meriwayatkannya dari Abū Mūsa al-'Asy'āri.

'Āisyah mengatakan:

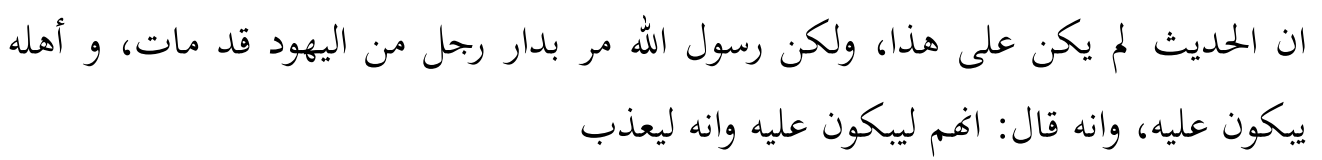

Babwa badis itu semestinya tidak begitu. Adalab Rasulullah saw suatu bari melewati rumah seorang Yahudi yang meninggal dunia. Sementara keluarganya menangisinya. Melihat hal itu, Beliau berkata "mereka menangisinya, sementara ia disiksa".

Kritik yang demikian juga dilontarkan pada Umar dan Ibn Umar dengan mengatakan semoga Allah memberi rahmat kepada Umar. Demi Allah, Rasulullah tidak menyabdakan bahwa Allah akan menyiksa seorang mukmin karena tangisan keluarganya, tetapi Rasulullah bersabda: "Sesungguhnya Allah akan menambah siksa orang kafir karena tangisan keluarganya". Lebih lanjut ia mengatakan: "Cukuplah bagi kalian untuk menolak riwayat ini dengan membaca ayat: "Dan seseorang yang berdosa tidak akan memikul dosa orang lain".

Al-Idlībi menjelaskan bahwa kritik 'Āisyah terhadap riwayat itu berdasarkan latar belakang hadis tersebut yang ia kemukakan dan menjadikan ayat al-Qur'an sebagai patokan, "Allah tidak membebani seorang hamba melainkan sesuai dengan kesanggupannya". ${ }^{51}$ Di sini juga jelas "Āisyah tidak mencurigai Umar, hanya beliau menjelaskan latar belakang sebenarnya. Oleh karenanya, tatakala berita itu sampai, 'Āisyah berkata: "Sesungguhnya kalian meriwayatkan hadis kepadaku bukan dari orang-orang yang berdusta, hanya saja mereka salah mendengar apa yang telah didengar." 52

Ketujuh, Sahabat melakukan kesalahan dengan meriwayatkan secara keliru apa yang tidak pernah dia dengar langsung dari Nabi saw (an yaqa'a labu ghalat fa yarwì wähiman 'an an-Nabi mä lam yasma'bu minhu). Untuk poin terakhir ini, al-Idlībi mengutipkan riwayat mengenai mayat dapat mendengar ucapan orang yang masih hidup.

Diriwayatkan dari an-Nasāài, Ibnu Umar menceritakan:

${ }^{51}$ Q.S. al-Baqarah: 286

${ }^{52}$ Ṣalāḥuddin bin Aḥmad al-Adlābī, Manhaj an-Naqd al-Matn 'Inda 'Ulamā al-Hadïs̀..., 114 


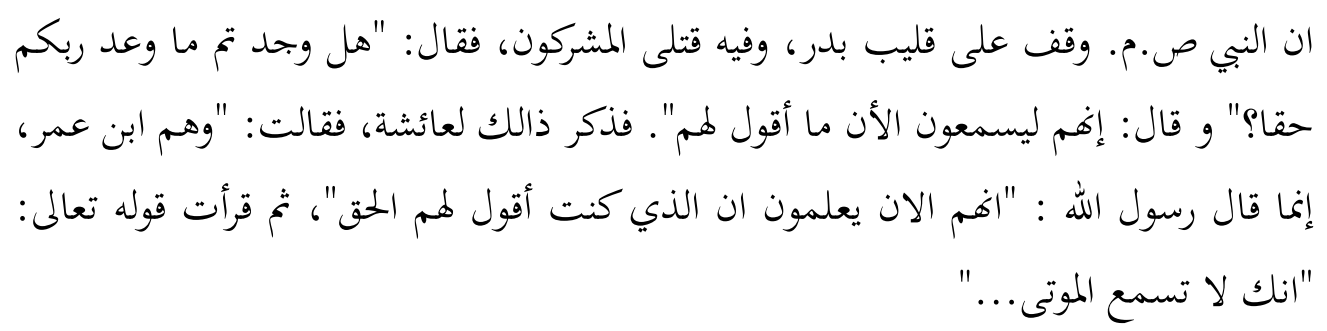

"Nabi saw (suatu ketika) bediri di tepi lubang bekas sumur Badar yang digunakan untuke tempat pembuangan mayat-mayat orang Quraisy waktu perang Badar. Ketika itu, Nabi saw bersabda: "Apakah kalian telah membuktikan janji tuhan-tuhan kalian itu benar?" lalu Nabi saw berkata lagi "sunggub mereka sekarang mendengar apa yang aku katakan kepada mereka." Riwayat tersebut lalu sampai kepada 'Aisyah, tatkala Aisyah mengetahuinya ia berkomentar "Tbnu Umar keliru dalam riwayat ini", yang sebenarnya Nabi saw bersabda: "Sesunggubnya mereka sekarang tabu bahwa apa yang telah aku katakan kepada mereka dabulu adalah benar adanya". Lalu Aisyah mengutip firman Allah swt "sesunggubnya kamu tidak dapat menjadikan orang mati mendengar dan tidak dapat menjadikan orang-orang yang tuli mendengar panggilan, apabila mereka telab berpaling membelakang. Dan kamu sekalikali tidak memimpin (memalingkan) orang-orang buta dari kesesatan mereka. Kamu tidak dapat menjadikan (seorang pun) mendengar, kecuali orang-orang yang beriman kepada Kami, lalu mereka berserah diri."

Al-Idlībi memaparkan bahwa dalam riwayat ini, 'Āisyah menjelaskan atau memberi kritikan pada kekeliruan Ibnu Umar ketika meriwayatkan hadis ini. Adapun keduanya tidak hadir dalam perang Badar tersebut. Barangkali Ibnu Umar mendapatkan riwayat ini dari salah seorang yang ikut perang Badar tersebut, seperti dari Ayahnya sendiri Umar bin al-Khattab.

Mengenai peristiwa ini, Bukhari dan Muslim juga meriwayatkannya dari Abu Talhah, bahwasanya Nabi saw, pada hari Badar menyuruh agar empat belas pemuka Quraisy ditimbun di dalam sumur bekas yang terdapat di Badar, lalu Nabi saw mulai memanggil nama-nama mereka dan bapak-bapak mereka: "Wahai fulan anak fulan, dan wahai fulan anak dari fulan apakah kalian menyesal tidak menaati Allah dan Rasul-Nya? adapun kami, sungguh telah kami dapati bahwa apa yang telah dijanjikan tuhan kami adalah benar (ditepati), apakah kalian (juga) telah membuktikan bahwa apa yang dijanjikan tuhan kalian adalah benar (ditepati?)"? Melihat dan mendengar apa yang dikatakan Nabi saw, Umar bertanya: "Ya Rasulullah saw, apa yang engkau bicarakan dengan jasad-jasad yang tidak ada jiwa di dalamnya?". Nabi saw menjawab: "Sungguh demi Zat yang jiwa ku berada di genggaman-Nya, kalian tidak lebih mendengar atas apa yang aku katakan dibandingkan mereka (mayat)."

${ }^{53}$ Q.S. an-Naml: $80-81$ 
Sikap Aisyah dalam mengkritik riwayat ini dilatarbelakangi oleh keyakinan terjadinya kontradiksi antara riwayat tersebut dengan ayat al-Qur'an yang menyatakan "sesungguhnya Engkau (Muhammad) tidak dapat menjadikan orang yang telah mati mendengar". Ayat ini dengan jelas menyatakan bahwa Nabi saw tidak bisa menjadikan orang yang mati mendengar perkataannnya, begitu pula orang yang tuli tidak dapat dijadikan mendengar seruannya, dan orang yang buta tidak dapat dijadikan melihat jika telah menyimpang dari jalan yang seharusnya.

Perkara yang indrawi ini, kemudian di-ta'wil-kan kepada perkara yang bersifat maknawi, bahwa dalam ayat ini, orang kafir disamakan dengan mayat, orang tuli dan orang buta. Hal tersebut dikarenakan pengingkaran dan bersikerasnya mereka terhadap kesesatan dan kelalaian, sedangkan orang mukmin juga disamakan dengan orang hidup, yang dapat mendengar dan dapat melihat, karena mereka mempercayai kebenaran dan mau mendengar, melihat (untuk ditaati) kebenaran tersebut.

Al-Idlibi lalu memaparkan bahwa dalam al-Qur'an diterangkan para Nabi saw memiliki kebiasaan setelah mendapatkan kemenangan dan berhasil menghancurkan musuh, para Nabi akan keluar menuju tempat-tempat hancurnya musuh lalu berseru dan berkata dengan perkataan yang menyakitkan dan menimbulkan penyesalan, misalnya Nabi Saleh dan kaumnya: "Karena itu mereka ditimpa gempa, maka jadilah mereka mayat-mayat yang bergelimpangan di tempat tinggal mereka. Saleh meninggalkan mereka seraya berkata: "Hai Kaumku sesunggubnya aku telah menyampaikan kepadamu, tetapi kamu tidak menyukai orang-orang yang memberi nasehat kepadamu, kamu tidak menyukai orang yang memberi nasehat.. ${ }^{54}$

Al-Idlïbi, setelah mengutip keterangan di atas menjelaskan, bahwa apa yang dilakukan Nabi saw sama dengan Nabi-nabi sebelumnya, namun apakah pembicaraan itu berkaitan langsung dengan mendengar dan memperdengarkan? lalu apakah kemampuan itu ditujukan kepada Jasad atau ruhnya?. Disinilah letak perbedaannya, Abdullah ibn Umar memahami bahwa pembicaraan ditujukan kepada Jasad, sehingga ia membenarkan bahwa mayat-mayat itu dapat mendengar pembicaraan Nabi saw. Adapun Aisyah mengkritik hal tersebut dan meyakini bahwa pembicaraan itu ditujukan pada ruh, sehingga diketahui bahwa kritik Aisyah ditujukan kepada kekeliruan Aisyah pada pemahaman Ibn Umar bahwa jasad mampu mendengar pembicaraan Nabi saw. ${ }^{55}$

\section{Analisa atas Bentuk Waham aṣ-Ṣahābah}

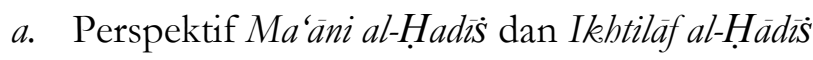

${ }^{54}$ Q.S. al-A'raf: 78-79

${ }^{55}$ Ṣalāḥuddin bin Aḥmad al-Adlābī, Manhaj an-Naqd al-Matn 'Inda 'Ulamā al-Hadïs..., 127 
Tidak bisa dipungkiri, upaya al-Idlibi dalam merumuskan tujuh bentuk waham yang dapat dilakukan oleh para sahabat merupakan kerja intelektual yang tidak mudah dan punya sumbangsih cukup signifikan kepada perkembangan keilmuan dan wacana ilmu hadis. Hal ini, selain dikarenakan kedudukan sahabat yang secara umum luhur di tengah umat Islam yang bisa saja menyebabkan adanya kekhawatiran jika mengulik sisi ke-waham-an sahabat karena dianggap sebagai tindakan kurang hormat kepada kedudukan mereka, juga bisa disebabkan sulitnya mengindikasi hadis-hadis yang di dalamnya terjadi waham.

Meski demikian, jika tujuh rumusan ini hendak dilihat dari kaca mata yang lebih luas, seperti dengan cabang ilmu hadis lain, maka sejatinya klaim atas waham ini bisa saja penilaian waham tersebut tidak disepakati oleh pihak lain. Sebagai contoh, bentuk waham pertama di mana al-Idlibi mengutip teguran Aisyah kepada Jabir karena keliru meriwayatkan hadis yang ternyata telah di-nasakh. Pada persoalan ini, jika kita melihatnya dari perspektif ilmu ikhtiläf al-hadis ternyata tidak semua ulama yang menyepakati terjadi nask $h$ atas hadis-hadis mengenai wajibnya mandi junub tersebut.

Dalam kitab Ikbtilǟ al-Hadìs bab al-Khiläf fi anna al-Gusla là yajïu illä bikhurüj al-Mä' terdapat narasi yang memberikan pandangan berbeda dari al-Idlibi. Bahwa beberapa ulama mazhab Syafi'i berpendapat bahwa tidak wajib bagi seorang lelaki mandi junub sampai keluar air mani. Kelompok ulama ini berdalih bahwa pernyataan Aisyah yang mewajibkan mandi selama telah bertemu dua kemaluan itu sifatnya sunnah (tatawwu), karena dalam keterangan itu Aisyah tidak dengan jelas menyebutkan bahwa Nabi saw sendiri yang menyatakan kewajiban mandi ('alaibi bi al-gus). Terkait hal ini Syafi'i berkomentar, bahwa Aisyah tidaklah menyatakan "apabila bersentuban satu kemaluan dengan kemaluan lainnya maka wajib mandi" tetapi ia mengatakan "aku berimak dengan Nabi dan setelab itu, kami mandi", sehingga dimungkinkan bahwa tatkala Aisyah melihat Nabi saw mandi, ia pun ikut mandi karena mengira bahwa hal itu wajib, disertai dengan kenyataan bahwa Aisyah tidak mendengar langsung dari Nabi akan kewajibannya secara tegas ${ }^{56}$

Contoh lain dapat ditemukan pada bentuk waham poin kelima, bahwa sahabat dapat salah memahami redaksi yang ia riwayatkan. Sebagai contoh dari poin ini, al-Idlibi mengutip riwayat Aisyah yang menegur Urwah bin Zubair yang dianggap waham dan tidak memahami hadis tentang wanita, keledai dan anjing hitam sebagai pembatal shalat. Hadis ini jika dipahami dengan pandangan ilmu ma'āni alhadïs, maka yang diriwayatkan oleh Urwah tersebut tidak menunjukkan bahwa ia waham, karena ketiga hal itu memang tidak bisa dimaknai secara tekstual melainkan sebagai bahasa simbol atau mająr. Yusuf al-Qaradhawi dalam kitabnya Kaifa Nata'ammal menyebutkan bahwa salah satu dari syarat memahami hadis dengan baik adalah membedakan mana bahasa yang menunjukkan makna hakiki dan

56 Abu Abdillah Muhammad bin Idris asy-Syafi'i, Ikbtiläf al-Hadiss, (Beirut: Dār alMa'rifah, 1990), Juz VIII, 606 
mana yang majazi (at-tafriq baina al-haqiqah wa al-majäri fi fahmi al-hadïs) ${ }^{57} \mathrm{Dalam}$ hal ini, kiranya hadis di atas bisa saja dipahami menggunakan lafal simbolis, yaitu perempuan sebagai simbol syahwat, keledai sebagai simbol gangguan dan anjing hitam sebagai simbol najis.

Kedua contoh di atas, terlepas perbedaan ulama di dalamnya, menunjukkan bahwa klaim al-Idlibi terhadap beberapa hadis sebagai bentuk waham yang dilakukan sahabat bukanlah penilaian yang bersifat pasti dan bukti tidak terbantahkan bahwa sahabat itu melakukan ke-waham-an. Sebagaimana yang telah kami paparkan di atas, bahwa ternyata ketika menggunakan sudut pandang lain, seperti ilmu ikbtiläf al-hadìs dan ma'āni al-hadìs, riwayat-riwayat tersebut tidaklah menunjukkan ke-waham-an sahabat, melainkan hanya perbedaan pendapat di kalangan mereka, atau juga karena menggunakan lafal simbolis yang perlu dimaknai secara lebih tepat.

b. Relevansi waham as-Sahabah dengan wacana keadilan Sahabat

Jika dicermati secara seksama mengenai konsep waham secara umum dan kriteria waham aṣ-șahäbah yang dirumuskan secara khusus oleh Al-Idlïbi, maka dapat dirumuskan dua analisa kaitannya dengan diskusi mengenai keadilan sahabat. Analisa pertama, kajian mengenai waham aṣ-șahäbah ini jika dilihat dari hubungan secara langsung ternyata tidak memiliki kaitan dengan keadilan sahabat itu sendiri, atau dalam arti kekeliruan yang dilakukan sahabat tidak berpengaruh pada kredibilitas keadilan mereka. Hal ini dapat dilihat dari poin penting dalam penjelasan Al-Idlibi bahwa kekeliruan termasuk sebab yang tidak disengaja, sehingga sama sekali bukan ranah perbincangan keadilan, melainkan ranah kedäbit -an yang bisa jatuh pada kekeliruan hadis.

Menurut Syuhudi Ismail, keadilan setidaknya memiliki empat unsur. Pertama, beragama Islam yang dimanifestasikan dengan bentuk keberimanan, ketaqwaan dan kepatuhan pada ajaran Islam. Kedua, mukallaf yang mencakup baligh dan berakal, karena titik penekanannya ada pada seseorang sadar atas perbuatannya dan memiliki rasa tanggung jawab. Ketiga, melaksanakan ketentuan agama yang terdiri dari teguh dalam agama, tidak berbuat bid'ah, tidak berbuat maksiat, tidak berbuat fasik dan baik akhlaknya. Keempat, menjaga murü'ah yang terletak pada pemeliharaan diri dari perbuatan halal yang bila dilakukan akan mengurangi kehormatan pribadi di mata masyarakat. ${ }^{58}$

Adapun ke-däbit-an berdasarkan beberapa pengertian yang diberikan oleh para ulama memiliki unsur sebagai berikut: (1) periwayat itu memahami dengan

\footnotetext{
${ }^{57}$ Yusuf al-Qaradhawi, Kaifa Nata'àmal ma'a as-Sunnah an-Nabawiyyah, (Kairo: Dār asySyurūq, 2004), 175

${ }^{58}$ Suyuhudi Isma’il, Kaedab Kesabihan sanad Hadis, (Jakarta: Bulan Bintang, 1995), 134
} 
baik riwayat yang telah didengarnya (diterimanya), (2) periwayat itu hafal dengan baik riwayat yang telah didengarnya (diterimanya), (3) periwayat itu menyampaikan riwayat yang telah dihafalnya itu dengan baik. ${ }^{59}$

Periwayat yang memenuhi seluruh unsur kememenuhi kriteria tamm dabt. Periwayat yang hanya memenuhi poin kedua dan ketiga hanya disebut periwayat yang dabt. Selain kedua itu, juga ada istilah khafif ad-dabt, yaitu periwayat yang terdapat dalam hadis hasan. ${ }^{60}$

Keterangan mengenai unsur keadilan dan ke-däbit-an ini menunjukkan bahwa, keadilan berbicara mengenai kualitas pribadi seseorang. Adil dalam aspek hadis menyangkut sisi akhlak, tabiat dan integritas pribadi atas ajaran-ajaran Islam. Adapun ke-dabbit-an, menyangkut kapasitas intelektualitas, yaitu segi hafalan, pemahaman dan cara menyampaikan. Dari kriteria intelektualitas, dabt juga terbagi menjadi dabt aș-sadr dan dabt al-kitäb. Dabt aș-sadr adalah periwayat yang hafal dan paham betul hafalan hadisnya, sementara dabt al-kitäb adalah periwayat yang mengetahui tulisan-tulisan riwayatnya sehingga jika ada kesalahan sekecil apapun dari tulisannya ia akan menyadarinya. ${ }^{61}$

Atas dasar penjelasan ini, kesimpulan penulis terbukti bahwa tujuh kriteria waham aș-Șahäbah Al-Idlībi secara eksplisit tidak memiliki sangkut paut dengan keadilan sahabat. Tujuh kriteria kekeliruan ini hanya menyinggung masalah hafalan, kecermatan, pengetahuan dan pemahaman sahabat yang bisa salah. Oleh karenanya, salah dalam hal ini bukan karena kesalahan yang disengaja, melainkan kesalahan yang tidak disengaja sehingga menyebabkan kekeliruan.

Analisa Kedua, meski tidak memiliki relevansi secara langsung dengan wacana keadilan sahabat, tidak serta merta menjadikan kriteria waham ini sama sekali tidak memberikan pengaruh atas wacana keadilan itu. Jika dicermati secara mendalam, kriteria ke-waham-an generasi sahabat ini justru menawarkan sebuah cara pandang baru dalam memandang perdebatan mengenai keadilan ini di antara dua pusaran antara pihak yang mendukung secara penuh tanpa membuka wilayah kajian terhadap generasi sahabat dengan pihak yang menolak secara mutlak dan menyangsikan keadilan sahabat.

Dalam pernyataan lainnya, diketahui bahwa Al-Idlïbi termasuk ulama yang meyakini bahwa semua Sahabat itu adil. Beliau menyatakan bahwa di antara para sahabat tidak ada yang mendustakan Nabi saw. Mereka adalah orang-orang yang rela mengorbankan jiwa raga demi menegakkan agamanya dan membantu dakwahnya. Allah swt memilih mereka sebagai pengemban amanah agama dan menyebarkan kepada generasi sesudahnya. Akan tetapi, sahabat tetaplah manusia

${ }^{59}$ Untuk poin yang ketiga terdapat perbedaan ulama. Ada ulama yang menyatakan bahwa menyampaikan dengan baik saat kapan saja dia kehendaki, sementara yang lain hanya mensyaratkan sampai saat dia menyampaikan riwayat itu ke orang lain.

${ }^{60}$ Syuhudi Isma'il, Metodologi Penelitian Hadis, (Jakarta: Bulan Bintang, 2007), 67

${ }^{61}$ Nuruddin 'Itr, Manhaj an-Naqd fi 'Ulum al-Hadis, (Beirutt: Dar al-Fikr, 1981), 81 
biasa. Meskipun secara umum mereka memiliki jiwa yang bersih dan daya hafalan yang kuat, tetapi mereka bukanlah orang-orang yang terpelihara dari kesalahan dan kekeliruan. ${ }^{62}$

Keterangan ini menunjukkan bahwa Al-Idlibi termasuk ulama yang mengakui keadilan sahabat, namun yang menariknya, keyakinan itu tidak serta merta menjadikan sahabat lepas dari objek kajian dan kritikan. Kriteria waham as Sabäbah yang ia tetapkan mengindikasikan bahwa kajian dan kritikan pada tingkat sahabat dilakukan tidak dalam ranah keadilan melainkan pada wilayah ke-dābit-an sahabat.

Adanya pengakuan atas keadilan sahabat dan ketidakberlepasan mereka dari kesalahan, menurut penulis sejatinya juga diakui oleh ulama-ulama lain yang sama meyakini konsep keadilan sahabat meski tidak dinyatakan secara langsung. $\mathrm{Hal}$ ini ditunjukkan dengan pengakuan atas adanya tingkatan-tingkatan sahabat yang berbeda-beda. ${ }^{63}$ Tingkat sahabat yang berbeda-beda ini menurut 'Ajjajj alKhațīb didasari dari berbagai aspek yang pada umumnya bisa dibagi menjadi dua; aspek keadilan dan pemahaman mereka atas ajaran Islam. Keadilan dalam hal ini terdiri dari ketaqwaan, kepatuhan, semangat ibadah dan pengorbanan yang telah mereka lakukan untuk memajukan Islam. Sementara ke-däbit-an menyangkut lamanya mereka mendapatkan pengajaran dan pendidikan dari Nabi saw, kesungguhan mereka dalam mendengar dan memperhatikan tingkah laku Nabi saw dan rasa penasaran mereka yang tinggi terhadap praktek hidup sesuai ajaran Islam. ${ }^{64}$

62 Șalāhuddin bin Aḥmad al-Adlabī, Manhaj an-Naqd al-Matn Inda 'Ulamā al-Hadïs anNabawì, (Beirut: Dar al-Afāq al-Jadīdah, 1983 M), 69

${ }^{63}$ Para ulama berbeda pendapat mengenai derajat atau tingkatan Sahabat. Ibnu Sa'ad membagi tingkatan Sahabat menjadi lima tingkatan, sementara al-Hakim membaginya menjadi dua belas. Pembagian tingkatan Sahabat yang terkenal adalah al-Hakim. Pembagiannya sebagai berikut: (1) kelompok Sahabat yang keislamannya paling awal, seperti Khalifah yang empat, (2) kelompok Sahabat yang keislamannya sebelum diadakannya musyarawah di Dār an-Nadwah, (3) kelompok Sahabat yang Hijrah ke Habasyah, (4) kelompok Sahabat yang mengikuti baiat 'Aqabah pertama, (5) kelompok Sahabat yang mengikuti baiat 'Aqabah kedua dan kebanyakan mereka dari kaum Anshar, (6) kelompok Sahabat yang dahulu berhijrah dan bertemu Nabi di Qubah sebelum masuk ke Madinah, (7)kelompok Sahabat yang mengikuti perang Badr, (8) kelompok Sahabat yang Hijrah di antara perang Badr dan perjanjian Hudaibiyah, (9) kelompok Sahabat yang ikut Baiat Ridwan di Hudaibiyah (10) kelompok Sahabat yang Hijrah di antara perjanjian Hudaibiyah dengan pembebasan Mekkah seperti Khalid bin Walid, Amr bin 'Ash dan Abu Hurairah, (11) kelompok Sahabat yang masuk Islam ketika pembebasan Mekkah, (12) kelompok Sahabat yang masih kecil namun sudah melihat Nabi saw pada pembebasan Mekkah atau ketika Haji Wada' atau yang lainnya. Muhammad 'Ajjaj Al-Khatib, Ușül al-Hadìs, 'Ulümubu wa Muștalahuhu, (Beirut: Dar alFIkr, 1971), 397

${ }^{64}$ Muhammad 'Ajjaj Al-Khatib, Ushul al-Hadis..., 396 
Keterangan ini memberikan kesimpulan dengan jelas bahwa ulama yang meyakini keadilan sahabat dan dengan tergesa-gesa melarang adanya kritikan apapun terhadap mereka, merupakan keyakinan yang kurang tepat dan menyalahi konsep ulama yang terdahulu. Tidak meyakini keadilan mereka juga terlalu gegabah, karena fakta bahwa mereka generasi yang amalan agamanya paling baik dan juga mendapat didikan langsung dari Nabi saw. Sikap yang paling moderat menurut penulis adalah sikap yang diambil Al-Idlïbi yaitu meyakini keadilan sahabat dengan segala konsep yang mengikutinya seperti kenyataan adanya tingkatan sahabat dan tanpa menutup mata adanya ruang untuk meneliti kean mereka.

\section{Kesimpulan}

Menurut Al-Idlībi periwayat hadis dalam tingkat sahabat pada kenyataannya tidak terlepas dari kemungkinan keliru dalam meriwayatkan hadis. Setidaknya ada tujuh bentuk kekeliruan yang bisa dilakukan oleh sahabat: (1) Sahabat itu meriwayatkan hadis yang didengarnya langsung dari Nabi saw, tetapi ia tidak tahu kalau hadis itu telah di-nasakh. (2) Sahabat mengalami kekeliruan dalam meletakkan dua hadis atau dua kata, sehingga meletakkan yang satu ke tempat yang satunya lagi (maqlüb). (3) Sahabat dalam meriwayatkan hadis, ia menyertakan komentarnya bersama dengan redaksi hadis itu, sehingga diduga oleh para pendengarnya bahwa itu bagian dari hadis (mudraj). (4) Sahabat meriwayatkan hadis dengan redaksinya sendiri yang memiliki cakupan lebih luas dari makna sebenarnya. (5) Sahabat keliru dalam menguasai dan memahami redaksi hadis sehingga menyelisihi makna sebenarnya. (6) Sahabat meriwayatkan hadis dengan maksud yang tidak benar karena lupa atau tidak tahu latar belakang penuturan hadis tersebut. (7) Sahabat melakukan kesalahan dengan meriwayatkan secara keliru apa yang tidak pernah dia dengar langsung dari Nabi saw.

Tujuh kriteria waham aș-șahăbah Al-Idlībi tidak memiliki hubungan yang signifkan dengan keadilan sahabat. Tujuh kriteria kekeliruan ini hanya menyinggung masalah hafalan, kecermatan, pengetahuan dan pemahaman sahabat yang bisa salah, di mana itu semua dalam wilayah ke-däbit-an. Oleh karenanya, salah dalam hal ini bukan karena kesalahan yang disengaja, melainkan kesalahan karena kekeliruan yang tidak disengaja. Namun demikian, meskipun AlIdlïbi termasuk ulama yang meyakini bahwa semua sahabat itu adil, namun keyakinan itu tidak serta merta menjadikan sahabat lepas dari objek kajian. Kriteria waham aș-șahäbah yang ia tetapkan mengindikasikan bahwa kajian dan kritikan pada tingkat sahabat dilakukan dalam wilayah ke-däbit-an mereka.

\section{Bibliografi}

Ad-Dārimī, Muḥammad bin Ḥibbān Abū Ḥātim, às-Śiqät, India: Dāirah al-Ma‘ārif al-Uśmāniyyah, $1973 \mathrm{M}$ 
Al-Anșāry, Zakaria, Syarh al-Fiyah al-Trāqy: Fath al-Bāqi, jilid 1, Beirut: Dār Kutub al-'Ilmiyyah, t.t,

Al-Arabi. Abu Bakar Ibn, al-Awāsim min al-Qawäsim fì Tahqüq Mawāqif aṣ-Ṣahābah ba'da Wafäh a-Nabi saw Beirut al-Maktabah al-Ilmiyyah, 1987

Al-As̀īi 'Izzuddīn Ibn, Usdu al-Ghäbah fì Ma'rifah aṣ-Șahăäah, Beirut: Dār al-Kutub al-Ilmiyyah, $1994 \mathrm{M}$

Al-'Asqalāni, Ibn Ḥajar, al-Iṣābah fì Tamyĩ̌ aș-Ṣahăbah, Beirut: Dār al-Kutub alIlmiyyah, $1415 \mathrm{H}$

Al-Baghdādi, al-Khațīb, al-Kifāyah fì Tlm ar-Riwàyah, Madinah: Maktabah alIlmiyyah, t.th

Al-Fāsyi, Al-Ḥāfiz Ibn al-Qațțān, Bayān al-W aham wa al-Iyham al-Waqi'inn fì Kitāb alAhkām, Jllid-1 Riyaḍ: Dar Ṭībah, 1997 M

Al-Idlībi, Șalāḥuddin Aḥmad, Manhaj Naqd al-Matn Inda 'Ulamä' al-Hadìs AnNabaw i Beirut: Dar al-Afaq al-Jadidah, 1983.

Al-'Izzī, Abd al-Mu'in Șalih al-Āli, Difä' an Abi Hurairah, Beirut: Dār al-Qalam, 1981

Al-Jā‘id, Anas, "al-Waham ‘inda Ruwwah al-Ḥadīs”’, Gaziosmanpaşa Üniversitesi İlahiyat Fakültesi Dergisi, 2 no. 1 (2014)

Al-Khațīb, Muhammad 'Ajjaj, Ușūl al-Hadīs, 'Ulūmubu wa Muștalahuhu, Beirut: Dār al-Fikr, 1971

Al-Manẓūr, Ibnu, Lisān al-'Arab, jilid 12, Beirut: Dār al-Fikr, 1410

Al-Qayyim, Ibn, Zād al-Ma'ād fì Hady Khair al-Tbād, Beirut: Dār al-Fikr li at-Tibā’ah wa an-Nasyr wa at-Tauzì', t.t.

An-Nawawi, at-Taqrīb wa at-Taysìr li Ma'rifah Sunan al-Basyìr an-Nà̃̀ir, Beirut: Dār al-Kitāb al-'Araby, $1985 \mathrm{M}$

An-Nasā’i, Sunan an-Nasā̉i, Beirut: Dār al-Kutub al-'Ilmiyyah, 2005

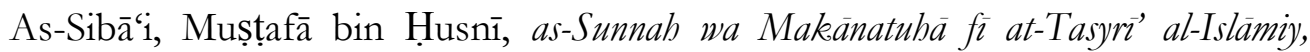
Beirut: al-Maktabah al-Islami, $1982 \mathrm{M}$

'Asror, Miftahul dan Imam Musbikin, Membedah Hadits Nabi Saw, Yogyakarta: Jaya Star Nine, 2015

At-Tirmiżī, Sunan at-Tirmiẓ̌̆, Beirut: Dār Kutub al-'Ilmiyyah, 2003

Aulassyahied, Qaem, "Skeptisisme dalam Hermeneutika Fatima Mernissi, Munazah Jurnal Kajian Gender 8 no. 2 (2016) 
78 | AL QUDS : Jurnal Studi Alquran dan Hadis vol. 5, no 1, 2021

Azami, Mustafa, Hadis Nabi saw dan Sejarah Kodifikasinya, Terj. Ali Mustafa Ya'qub Jakarta: Pustaka Firdaus, 1994

Aż-Żahabī, Syamsuddīn, Mirāan al-I'tidāl fì Naqd ar-Rijaäl, Beirut: Dār al-Ma'rifah, $1963 \mathrm{M}$

Az-Zarkasyi, Badaruddin, al-Ijäbah li Iradi Mā Istadrakathu 'Āisyah 'ala aṣ-Ṣahäbah, Beirut: al-Maktab al-Islamy, 1970

Bahu, Abu Yūsuf Muștāfa, al- "illah wa Ajnāsuba inda al-Muhaddišñn, Thanta: Dār aụ-Diyā, 2005 M

Dāwūd, Abū, Sunan Abì Dāwñ̀d, Beirut: Dār al-Kutub al-'Tlmiyyah, 2007

Fadilah, Nur, "Keadilan Sahabat Nabi dalam Perspektif Fuad Jabali, Mutawatir Jurnal Keilmuan Tafsir Hadis 2 no.1 (2012)

Itr, Nūruddīn, Manāhij al-Muhaddisīn al-ámmah fì Riwāyah wa at-Taṣnif, Damaskus: Dār Thayyibah ad-Dimasyqiyyah, 2008 M Manhaj an-Naqd fì 'Ulüm al-Hadïs (Beirut: Dar al-Fikr, 1981

Ismail, Syuhudi, Kaedah Kesahihan Sanad Hadis, Jakarta: Bulan Bintang, 1995 , Metodologi Penelitian Hadis, Jakarta: Bulan Bintang, 2007

Jabali, Fuad, Sahabat Nabi saw, Siapa, Ke Mana, dan Bagaimana?, Jakarta: Mizan, 2010

Mājah, Ibn, Sunan Ibn Mäjah, Indonesia, Maktabah Dahlan, t.t

Mernissi, Fatima, Perempuan Dalam Islam, Bandung: Pustaka, 1994 M

Nafisah, Lailiyatun, Moh, Muhtador, "Wacana Keadilan Sahabat Dalam Pandangan Ulama Klasik dan Kontemporer" Al-Quds: Jurnal Studi Alquran an Hadis 2, no.2 (2018): 153-170, doi: 10.29240/alquds.v2i2.429.

Rayyah, Mahmud Abu, Adhwa 'ala as-Sunnah al-Muhammadiyah, Kairo: Dar alMa'arif, t.th

Șalaḥ, Ibnu, Muqaddimah Ibnu Șalah, (Kairo: Dār al-Ma’ārif, t.t

Syaibah, Ibn Abī, al-Mușannaf, Riyadh: Maktabah ar-Rusyd, 1409

Syuhbah, Abū, Difä' 'an Sunnah wa Radd Syubh al-Mustasyriqin wa al-Kitäb alMu'ashirin, Kairo: Majma' al-Buhūì al-Islamiyyah, 1985 M

Kamus Besar Bahasa Indonesia, Jakarta: Balai Pustaka, 2005

https:www.idlbi.net. 